\author{
超LSI対応レーザー不純物活性化技術 \\ 松野明 ${ }^{1,2}$, 榆 孝 ${ }^{1}$, 芝原 健太郎 2 \\ 1フェトン(株) (テ243-0021 神奈川県厚木市岡田3050 厚木アクストメインタワー4F IBルーム III) \\ 2広島大学ナノデバイス・システム研究センター (テ739-8527 広島県東広島市鏡山1-4-2)
}

\title{
Laser Annealing Process for ULSI Technology
}

\author{
Akira MATSUNO ${ }^{1,2}$, Takashi NIRE ${ }^{1}$, and Kentaro SHIBAHARA ${ }^{2}$ \\ ${ }^{1}$ Phoeton Corp., Atsugi AXT Main Tower 4F IB room II, 3050 Okada, Atsugi, Kanagawa 234-002I \\ ${ }^{2}$ Research Center for Nanodevices and Systems, Hiroshima University, \\ 1-4-2 Kagamiyama, Higashi-Hiroshima, Hiroshima 739-8527
}

(Received December 16, 2004)

\begin{abstract}
Using $\mathrm{KrF}$ excimer laser annealing with various laser pulse durations, we were able to form an ultra-shallow junction. Evaluating junction depth, sheet resistance, and crystal defects, we observed that in the case of long pulse durations, the number of crystal defects decreased. The combination of the junction depth and sheet resistance of the junction satisfied the request for a 90 -nm node for ULSI. Furthermore, a MOSFET was fabricated by laser annealing with a heat assist. The heat assist is effective for reducing the required laser energy, crystal defects in the junction, and reducing laser damage to the electrode. We employed a simple onedimensional thermal diffusion model to estimate the solidification velocity during laser irradiation, with results indicating that longer pulse duration slowed the solidification velocity. Therefore, the behavior of the solidification velocity can explain the reduction of crystal defects.
\end{abstract}

Key Words: Shallow junction laser anneal ULSI

\section{1.はじめに}

半導体集積回路の集積度の増大は，1965年に提唱され た「半導体の集積度は18２4ヶ月で倍増する」という， ムーアの法則に今日に至るまで従っている。微細化を推 し進めるにつれて, 種々の課題が明らかにされてきた が, 集積回路の構成素子であるMOS FET (Metal Oxide Semiconductor Field Effect Transistor)の性能向上は，「短 チャネル効果」と呼ばれる, 寸法の縮小に伴う特性変動と の戦いの連続であった．本稿で取り上げる極浅接合形成 は, 短チャネル効果抑制の最も基本的な方策である。

MOS FETはFig. 1に示すようにゲート，ソース，ドレイ ンの3電極を持つ半導体素子であり, ソースードレイン間 を流れる電流を絶縁膜を介して設けられているゲート電 極に加える電圧で制御する。ソース・ドレイン部は基板 と反対の導電型にドープされ，pn接合を形成している. 基板にp型シリコンを用いる場合，ゲート電圧が低く基板 内の電位分布に影響を与えない状態では, ソースードレ イン間にバイアス電圧 $\left(V_{\mathrm{SD}}\right)$ を加えても，ソース側 $\mathrm{pn}$ 接合 部の電位障壁をキャリアが乗り越えられず，電流は流れ ない．それに対して，ゲート電圧 $\left(V_{\mathrm{G}}\right)$ を加えるとゲート 絶縁層直下に反転層が形成され，ソース端pn接合部の電 位障壁が低下し， $V_{\mathrm{SD}}$ を印加すれば，ソースードレイン間
に電流 $\left(I_{\mathrm{D}}\right)$ が流れる。このような原理によって， $V_{\mathrm{G}}$ に よって $I_{\mathrm{D}}$ 制御することが出来る。しかしながら，ゲート 長が短縮されるに伴い $V_{\mathrm{SD}}$ によりドレイン側pn接合の周囲 に形成された空乏層のチャネルに対する影響が大きくな り， $I_{\mathrm{D}}$ が $V_{\mathrm{G}}$ で制御できなくなるという短チャネル効果が現 れる。

短チャネル効果抑制には，ドレイン側pn接合の周囲に 形成される空乏層を小さくするため, ソース・ドレイン 接合を浅く，急峻にすることが有効である。また，素子 の高性能化のためには，このソース・ドレインの抵抗を 低く抑える必要もある。この目標值を示すものとして ITRS (International Technology Roadmap for Semiconductors) が公表されている1).この一部をTable 1に示す。この特性

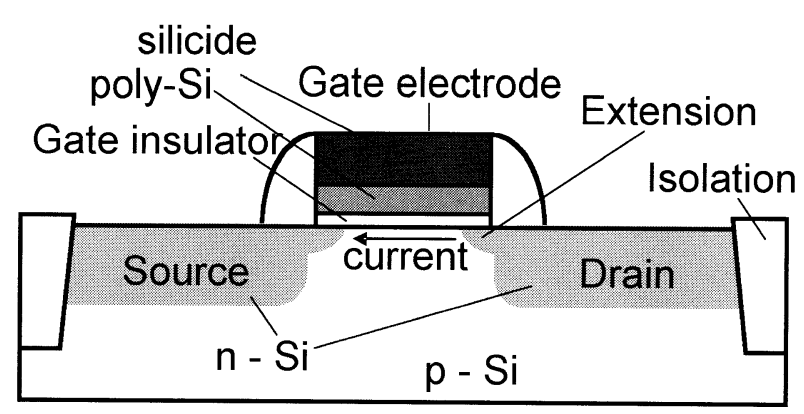

Fig. 1 Schematic diagram of MOS FET. 
Table 1 A part of International Technology Roadmap for Semiconductors. ${ }^{1)}$

\begin{tabular}{|c|c|c|c|c|c|c|c|}
\hline Year of Production & 2003 & 2004 & 2005 & 2006 & 2007 & 2008 & 2009 \\
\hline Technology node & & hp90 & & & hp65 & & \\
\hline DRAM 1/2 Pitch (nm) & 100 & 90 & 80 & 70 & 65 & 57 & 50 \\
\hline MPU/ASIC $1 / 2$ Pitch (nm) & 107 & 90 & 80 & 70 & 65 & 57 & 50 \\
\hline MPU Printed Gate Length (nm) & 65 & 53 & 45 & 40 & 35 & 32 & 28 \\
\hline MPU Physical Gate Length (nm) & 45 & 37 & 32 & 28 & 25 & 22 & 20 \\
\hline Drain extension $\mathrm{Xj}(\mathrm{nm})$ & 24.8 & 20.4 & 17.6 & 15.4 & 13.8 & 8.8 & 8 \\
\hline $\begin{array}{l}\text { Maximum drain extension sheet } \\
\text { resistance }(\mathrm{PMOS})(\Omega / \mathrm{sq})\end{array}$ & 545 & 663 & 767 & 833 & 884 & 1739 & 1800 \\
\hline $\begin{array}{l}\text { Maximum drain extension sheet } \\
\text { resistance (NMOS) }(\Omega / s q)\end{array}$ & 255 & 310 & 358 & 389 & 412 & 811 & 840 \\
\hline
\end{tabular}

を満たすプロセスの候補として，低エネルギーイオン注 入法2) と種々のアニール技術3-7) を組み合わせたプロセスの 開発が進められている。特に $\mathrm{KrF}$ エキシマレーザーを用い たレーザーアニールは，その波長 $(248 \mathrm{~nm})$ におけるSiの吸 収係数が非常に大きいため, nsオーダーの極短時間加熱に 加えて，ウェー八の表層部( 〜数十nm)のみを加熱できる ため冷却に要する時間が短く，不純物拡散の抑止という 点から望ましい技術ということが出来る7-9).さらに，工 キシマレーザーを用いSi表面の一部を溶融させるプロセス も提案されている ${ }^{8)}$. この場合，溶融して液相化した部分 と, 固相のままの部分での不純物拡散係数が大幅に異な り, 液相中での拡散が圧倒的に速いため, 導入した不純 物が融解層にほぼ一様に広がることになり，低抵抗化に 有利な不純物分布 (ボックス型分布)を得ることが出来る. また，結晶化が非平衡状態で進むため, 固溶限を超える ドーピングが可能であることから，低抵抗化に対し更に 有効な技術である。しかしながら，溶融再結晶化した領 域では残留欠陥が生じ，素子のリーク電流の原因となっ ている99. 本稿の以下の部分では，レーザーアニールによ る溶融再結晶化の際に生じる残留欠陥を低減するため に，エキシマレーザーのパルス幅に着目し，筆者らが(株) 小松製作所在職中に広島大学と共同で実施したエキシマ レーザーアニール10,11)について述べる。

\section{2. 実 験}

サンプルには，ゲルマニウム $(\mathrm{Ge})$ イオンを加速エネル ギー5 keV, ドーズ量 $1 \times 10^{15} \mathrm{~cm}^{-2}$, ホウ素 $(\mathrm{B})$ イオンを 加速電圧 $0.5 \mathrm{kV}$, ドーズ量 $5 \times 10^{14} \mathrm{~cm}^{-2}$, でイオン注入を 行ったSiウェー八 (100)面を用いた。この場合，表面の 12 $\mathrm{nm}$ の部分は, $\mathrm{Ge}$ 注入によりアモルファス化されている.

$\mathrm{KrF}$ エキシマレーザーを用い，パルス幅 $10 \mathrm{~ns}, 33 \mathrm{~ns}, 38$ ns, $55 \mathrm{~ns}, 62 \mathrm{~ns}$ のレーザービームを先のウェーハに照射 し, そのシート抵抗を拡がり抵抗測定法で測定し, 不純 物の深さ方向の濃度分布をSIMS (Secondary Ion Mass Spectrometry:2次イオン質量分析法)を用いて評価した。ま た，結晶欠陥を透過電子顕微鏡で評価した。

パルス幅10 nsのレーザービームはビームエキスパン ダ，マスク及び縮小転写レンズを用いてサンプル上で1 $\mathrm{mm} \times 1 \mathrm{~mm}$ のビームサイズになるように整形し，またパ ルス幅 $33 \mathrm{~ns}$ のレザービームは同様に $3.8 \mathrm{~mm} \times 3.8 \mathrm{~mm} に$
整形した。パルス幅33 nsのレーザービームはフライアイ レンズを用いたビームホモジナイザー及び縮小転写光学 系を用いて， $4 \mathrm{~mm} \times 4 \mathrm{~mm}$ のビームに整形した. $55 \mathrm{~ns}$ 及 び62 nsのパルス幅のレーザービームは, $33 \mathrm{~ns}$ のパルス幅 のレーザービームをビームスプリッターで2分し，その一 方のビームをディレイ光学系を通した後, もとのビーム に重畳させて得た。 $55 \mathrm{~ns}$ 及び62 nsのパルス幅のレーザー ビームもパルス幅3 $3 \mathrm{~ns}$ のレーザービームと同様の均一照 明光学系及び転写光学系を用いて $4 \mathrm{~mm} \times 4 \mathrm{~mm}$ のビームに 整形した。

FETを作製する際には，プロセスがゲート電極形成の後 にイオン注入，レーザー照射という順序になるので， レーザー照射によるゲート電極に対するダメージが懸念 された，後に述べる熱伝導シミュレーションの結果か ら, Fig. 9に示されるように, レーザー照射時に基板を加 熱することにより，アモルファス層のみを溶融させるた めに必要なエネルギー密度が低減できる可能性が示され たので, 前述のウェー八を $350{ }^{\circ} \mathrm{C}$ 及び $450{ }^{\circ} \mathrm{C}$ に加熱しレー ザー照射を行い同様の評価を行った。この際に使用した レーザーのパルス幅は38 nsであった。

FETの特性を評価するために，ゲート電極パターンを形 成後にイオン注入を施したデバイス作製途中のサンプル

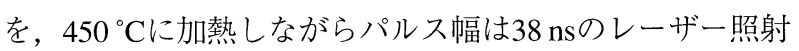
を施し，その後通常のプロセスを用いて素子を作製し， その電気特性を評価した。

\section{3. 実験結果と考察}

Fig. 2に各パルス幅のレーザービームを照射した際の深 さ方向の不純物分布の照射エネルギー密度依存性を示 す。これから，図中でas implaと描かれている曲線は， レーザー照射前の分布を示している。これから，照射エ ネルギー密度が低い場合には，不純物分布がレーザー照 射を行っていないものとほぼ変わらず，エネルギー密度 を上げるに従って，Bの分布がエネルギー密度依存性の小 さい状況が出現し, そのあとは, エネルギー密度の増加 に従い不純物が涾く拡散していることがわかる.

これは，それぞれのパルス幅について2つの特徵的なエ ネルギー密度が存在するためと考えられる。1つは結晶 $\mathrm{Si}$ に比べ, 融点の低いアモルファス層を融解させるために 必要なエネルギー密度であり, 他方は, 結晶Siを融解させ 

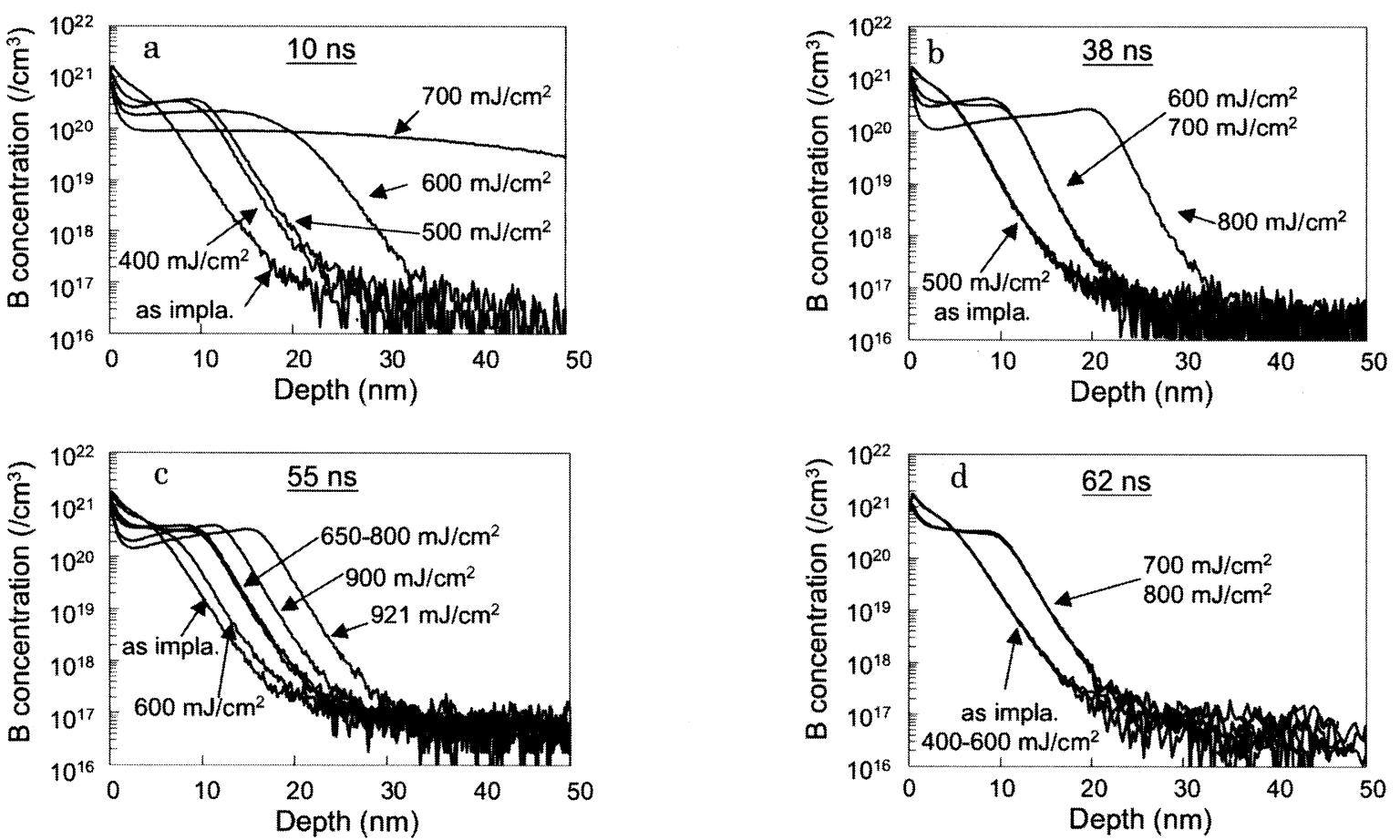

Fig. 2 Boron depth profile of evaluated by SIMS for laser pulse duration of (a) $10 \mathrm{~ns}$, (b) $38 \mathrm{ns,} \mathrm{(c)} 55$ ns and (d) 65 ns. ${ }^{9)}$

るために必要なエネルギー密度である。アモルファス層 を融解させるエネルギー密度よりも低エネルギー密度で は，加熱時間が短いため，不純物の再分布もSIMSでほと んど差異が見られぬほど小さい。これに対して，アモル ファス層を融解させるエネルギー密度と結晶 $\mathrm{Si}$ 融解させ るエネルギー密度の間のエネルギー密度で照射を行った 場合には, アモルファス層は全て融解し, 結晶Siは融解し ない。液相でのBの拡散係数が非常に大きいことから，B は融解したアモルファス層全体に広がる。Bの分布のエネ ルギー密度依存性の小さい部分は，この状況に対応して いると思われる。さらにエネルギー密度を上げた場合に は, 結晶Siも融解するため, Bはさらに深く拡散する。接 合深さの点から，最適なエネルギー密度は，アモルファ ス層のみを融解させる範囲にあると考えられる。拡散の 程度を示すパラメータとしてB濃度が $1 \times 10^{18} \mathrm{~cm}^{-3}$ となる 深さを接合深さと定義する。接合深さと照射エネルギー 密度の関係及び接合深さとシート抵抗の関係をFig. 3及び Fig. 4に示す. Fig.4から同じ接合深さでも，照射するビー ムのパルス幅が長いほど，シート抵抗が下げられること がわかる。

Fig. 5に示す断面透過電子顕微鏡写真によれば，パルス 幅10 nsのビームを照射した場合，表面層にははっきりと した結晶構造が見られず，欠陥の多い多結晶とアモル ファス相の混合層になっていることがわかる。また，パ ルス幅38 nsのビームを照射したものには，アモルファス 層とSi基板の境界から，表面に向かって結晶成長している ものの，直線状の双晶と呼ばれる欠陥が見られる。これ に対し，パルス幅55 nsのビームを照射したものは，表面 の欠陥がまったく見られない。これから，パルス幅の短 いビームを照射したサンプルのシート抵抗が高いのは, これらの欠陥によるキャリアの散乱が多いためと考えら

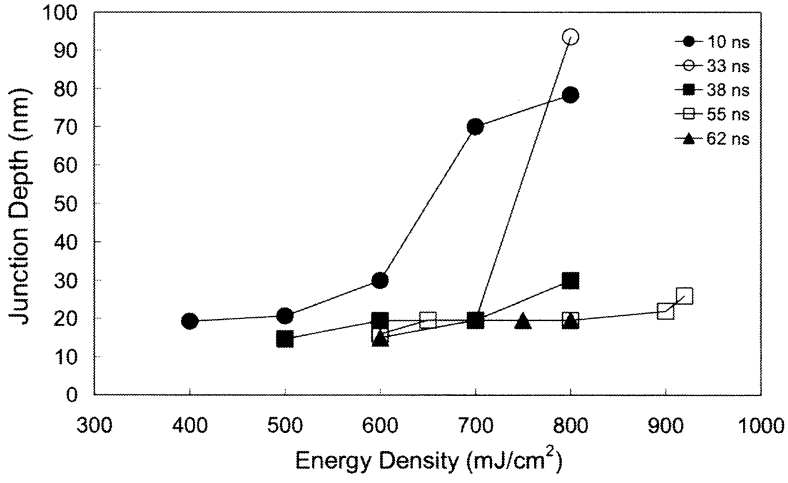

Fig. 3 Dependence of laser irradiation energy density on sheet resistance. ${ }^{9)}$

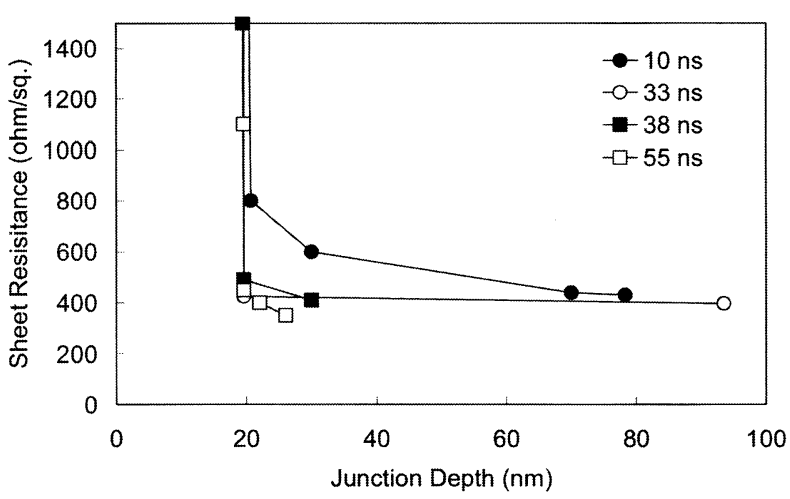

Fig. 4 Relationship between junction depth and sheet resistance for each pulse width.

れる。

Fig. 6に基板加熱を併用したレーザーアニールによって 得られた接合の接合深さと，シート抵抗の関係を示す。 これから，基板を $350{ }^{\circ} \mathrm{C} \sim 450{ }^{\circ} \mathrm{C}$ に加熱することにより， 


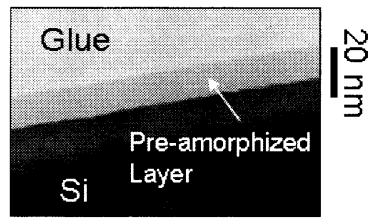

as implanted

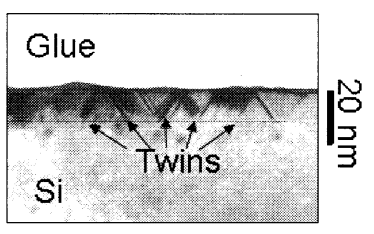

$38 \mathrm{~ns} 700 \mathrm{~mJ} / \mathrm{cm}^{2}$

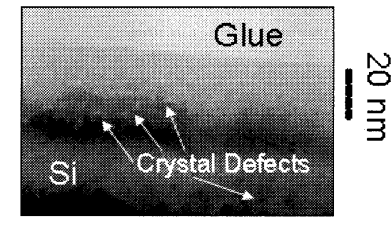

$10 \mathrm{~ns} 600 \mathrm{~mJ} / \mathrm{cm}^{2}$

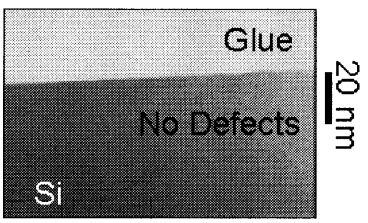

$55 \mathrm{~ns} 921 \mathrm{~mJ} / \mathrm{cm}^{2}$

Fig. 5 Cross sectional TEM image pre and post laser annealing. ${ }^{9)}$

活性化に必要とされる(接合深さ $20 \mathrm{~nm}$, シート抵抗 $1000 \Omega$ 以下) レーザー照射エネルギー密度は基板加熱の無い場合 に比べほぼ半減していることがわかる。

パルス幅の短いビームを照射した場合に欠陥が多い理 由を, 溶融した後に凝固する際の固加速度が早すぎるた めと考え, 簡単な1次元熱伝導シミュレーションを試み た、レーザー照射による発熱を含む1次元熱伝導方程式は 式(1)で示される.

$$
c \rho \frac{\partial T}{\partial t}=\frac{\partial}{\partial x}\left(k \frac{\partial T}{\partial x}\right)+\alpha(1-R) I(x, t)
$$

$c$ は比熱， $\rho$ は密度，Tは温度， $k$ は熱伝導率， $\alpha$ は吸収係 数，Rは反射率である．Iはレーザービームの強度である。 レーザーのパルス波形は三角波を仮定しており，立ち上 がり時間を $5 \mathrm{~ns}$ とし立下り時間を変化させてパルス幅を変 えている，計算に用いたモデルは，表面に $15 \mathrm{~nm}$ のアモル ファスシリコン $(\mathrm{a}-\mathrm{Si})$ 層を持つSiである。実際の計算に用 いたパラメータをTable 2に示す. 熱伝導率の温度依存 性 ${ }^{2)}$ を考慮したため，式(1)を差分法を用いて解いた， Si の融解に関しては, a-Siの融点が結晶 $\mathrm{Si}$ の融点より $300{ }^{\circ} \mathrm{C}$ 低いと仮定し13), 融点において吸収熱量が融解潜熱に達 するまでは温度は融点に留まると仮定した。

Fig. 7にパルス幅毎の，レーザーエネルギー照射密度と 溶融深さの計算結果を示す。これは, 先に示した実験結

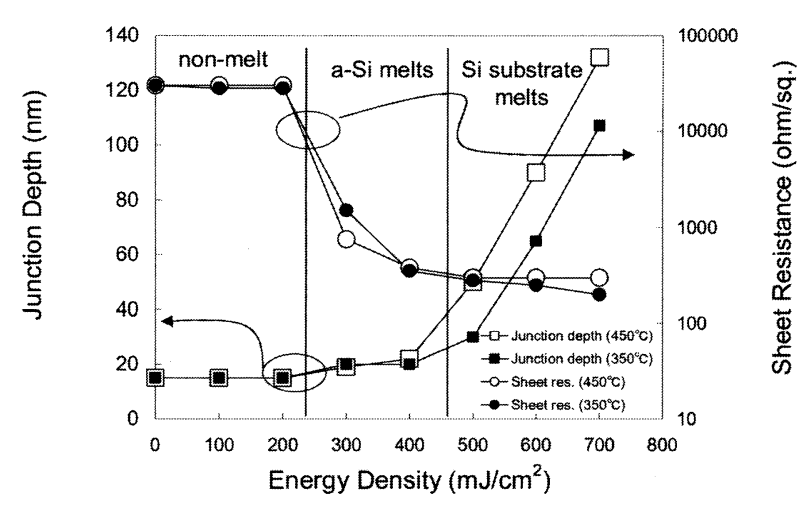

Fig. 6 Dependence of laser irradiation energy density on junction depth and sheet resistance in case of heat assisted laser annealing. ${ }^{9)}$

Table 2 Parameters used in this simulation. ${ }^{10)}$

\begin{tabular}{cccc}
\hline & crystal & amorphos & liquid \\
\hline $\mathrm{c}(\mathrm{J} / \mathrm{g} \mathrm{K})$ & 0.707 & 0.707 & 0.707 \\
$\rho\left(\mathrm{g} / \mathrm{cm}^{3}\right)$ & 2.33 & 2.33 & 2.33 \\
$\mathrm{k}\left(\mathrm{W} / \mathrm{cm} \mathrm{K}^{3}\right)$ & $0.235+4.45 \exp (-\mathrm{T}(\mathrm{K}) / 247)$ & $0.235+4.45 \exp (-\mathrm{T}(\mathrm{K}) / 247)$ & 0.67 \\
Latent Heat $(\mathrm{J} / \mathrm{g})$ & 1800 & 1250 & - \\
$\alpha\left(\mathrm{cm}^{-1}\right)$ & $2 \times 10^{6}$ & $2 \times 10^{6}$ & $2 \times 10^{6}$ \\
$\mathrm{R}$ & 0.68 & 0.68 & 0.7 \\
m.p.(K) & 1687 & 1387 & - \\
\hline
\end{tabular}

果において，接合深さを溶融深さと読み替えた場合と定 性的に一致する，溶融深さが減少し始めてから，固化が 完了するまでの時間を固化時間と定義し, 固化時間で, 溶融深さを割ったものを固化速度と定義する．パルス幅 毎の固化速度と, レーザーエネルギー密度の関係をFig. 8 に示す。これから, パルス幅が長いほど, 固化速度が遅 くなることがわかる．断面TEM写真に見られたパルス幅 の長いレーザーを用いると欠陥が減るという結果は，パ ルス幅の長くなると, 固化速度が減少するために結晶成 長中に欠陥が入りにくくなるということで説明が出来 る.

Fig. 9に基板温度を $27^{\circ} \mathrm{C}(300 \mathrm{~K}), 250{ }^{\circ} \mathrm{C}(523 \mathrm{~K}), 350{ }^{\circ} \mathrm{C}$

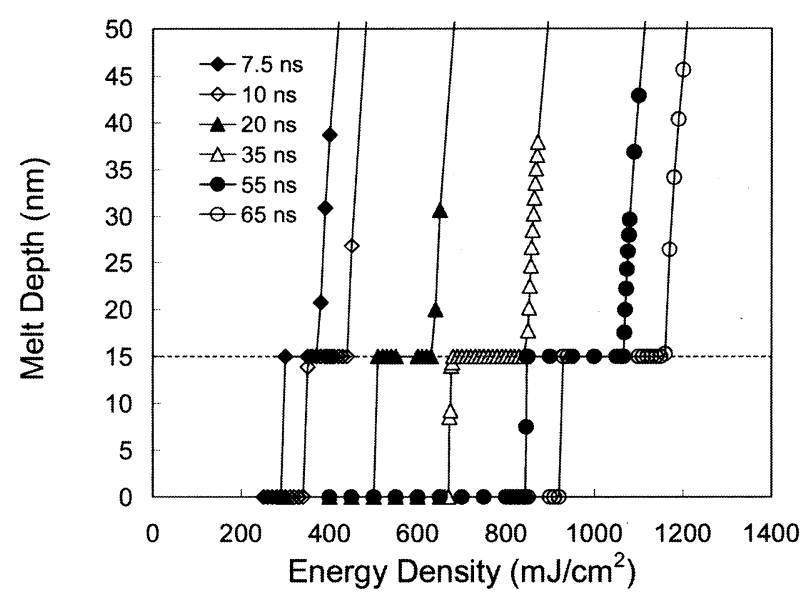

Fig. 7 Calculated melt depth vs. laser irradiation energy density for each pulse duration. ${ }^{10)}$ Dashed line represents the depth of pre-amorphized layer. Flat region of each graph shows the energy density range to melt only pre-amorphized layer.

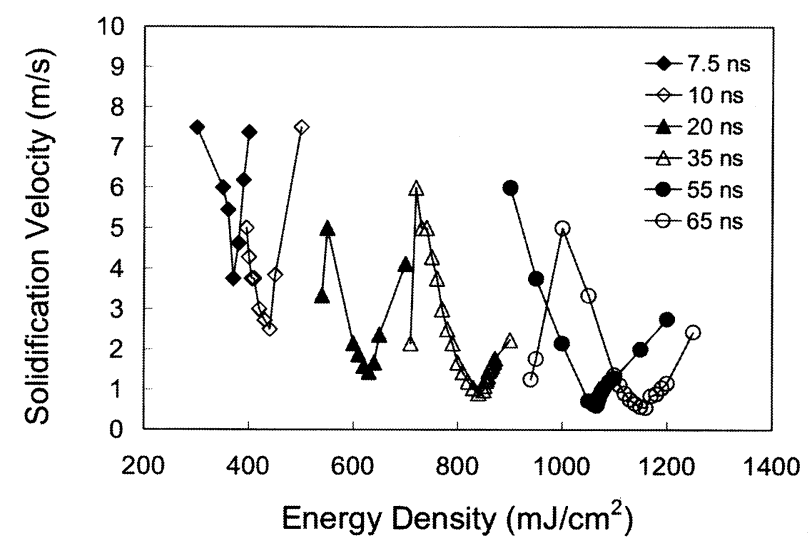

Fig. 8 Calculated solidification velocity vs. laser irradiation energy density for each pulse duration. ${ }^{10}$ ) 
$(623 \mathrm{~K}), 450{ }^{\circ} \mathrm{C}(723 \mathrm{~K})$ としたときのレーザーエネルギー 照射密度と溶融深さの計算結果を示す。この結果から, レーザー照射時に基板加熱を併用することにより，アモ ルファス層のみを溶融させるために必要なエネルギー密 度を，低減できることがわかる．基板温度を $350{ }^{\circ} \mathrm{C}, 450$ ${ }^{\circ} \mathrm{C}$ と設定したときに $300 \mathrm{~mJ} / \mathrm{cm}^{2} \sim 400 \mathrm{~mJ} / \mathrm{cm}^{2}$ のエネルギー 密度でアモルファス層のみを溶融できるという計算結果 は，Fig. 6の実験結果とほぼ一致している。

Fig. 10に広島大学との共同研究で試作した基板加熱を併 用したエキシマレーザーアニール法を接合形成に用いた

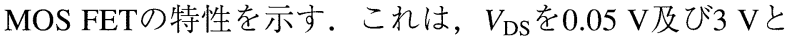
設定し $V_{\mathrm{G}}$ を-0.5 Vから $5 \mathrm{~V}$ まで変化させたときの $I_{\mathrm{D}}$ の変化 を示したものである．この結果から， $V_{\mathrm{G}}$ を変化させるこ とにより $I_{\mathrm{D}}$ 増加しており， MOSFETとしての動作して いることがわかる.これから，基板加熱はゲート電極夕゙ メージ低減の有力な手段であることがわかる.

\section{4. 結 論}

レーザーアニールプロセスは，ITRSに示されている接 合深さとシート抵抗を満足させるだけであれば，それを クリアできる実力は十分に有している。しかしながら， 実際のデバイス製造に適用するとなると，アニール特性 にウェーハ上に形成されているパターン依存性がある， 装置の安定性・再現性に不安がある，プロセス中のモ二 タリングが困難などの課題もある。しかしながら $65 \mathrm{~nm}$ node以降の活性化技術に対してまだ決定的な解答が得られ ていない現状では，有力な解答の候補として今後研究を 続けてゆく必要がある。

\section{謝 辞}

本研究の一部は，NEDO/MIRAIプロジェクトに支援に より遂行した。イオン注入ウェーハを提供いただいた 峰地 輝氏に感謝いたしますとともに研究を遂行したコマ ツ研究本部の方々に感謝いたします.

\section{参考文献}

1) International Technology Roadmap for Semiconductors (2003).

2) 鈴木良守：月刊Semiconductor World (1997) 77.

3) T. Matsuda, S. Shishiguchi, and H. Kitajima: Ext. Abst. first International Workshop on Junction Technology (2000) 29.

4) A. Agarwal：応用物理学会，シリコンテクノロジー $19(2000)$ 3.

5) T. Ito, T. Iinuma, A. Murakoshi, H. Akutsu, K. Suguro, T. Arikado, K. Okumura, M. Yoshioka, T. Owada, Y. Imaoka, H. Murayama, and T. Kusuda: Jpn. J. Appl. Phys. 41 (2002) 2394.

6) S. Talwar, D. Markle, and M. Thompson: Solid State Technology July (2003) 83

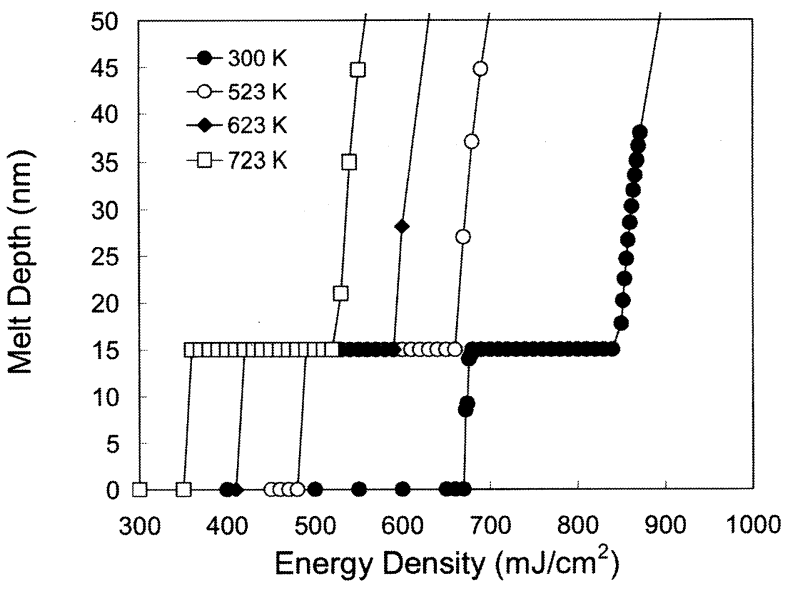

Fig. 9 Calculated melt depth vs. laser irradiation energy density for heat assisted laser annealing. ${ }^{10)}$

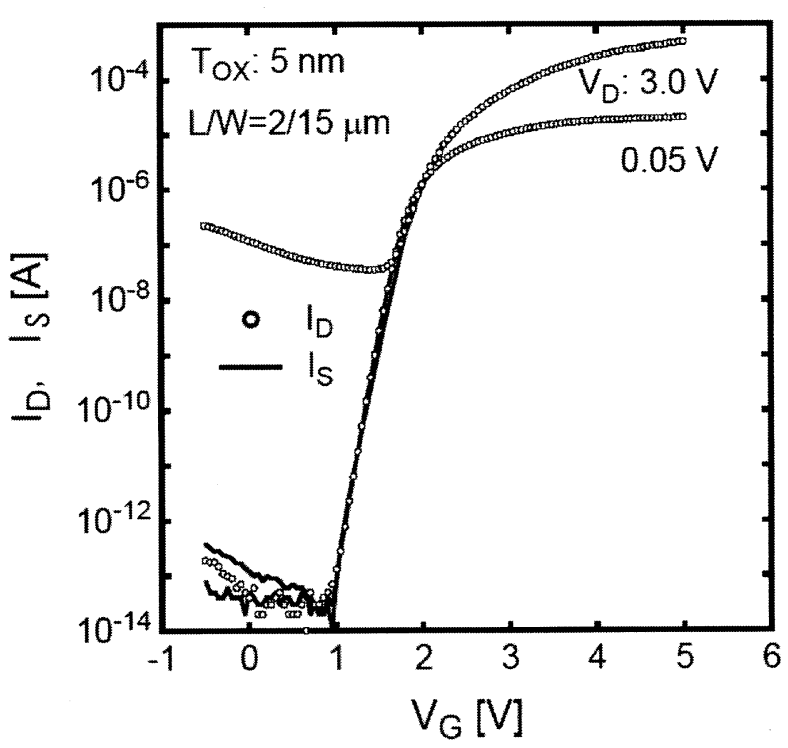

Fig. $10 \mathrm{Ig}-\mathrm{Vd}$ characteristic of FET which source and drain junction was formed by laser annealing.

7) B. Yu, Y. Wang, H. Wang, Q, Xiang, C. Riccobene, S. Talwar, and M.-R. Lin: IEDM-99, IEEE (1999) 348.

8) T. Yamamoto, K. Goto, T. Kubo, Y. Wang, T. Lin, S. Talwar, M. Kase, and T. Sugii: Ext. Abst. third International Workshop on Junction Technology (2002) 27.

9) K. Goto, T. Yamamoto, T. Kubo, M. Kase, Y. Wang, T. Lin, S. Talwar, and T. Sugii: IEDM-99, IEEE (1999) 931.

10) K. Kagawa, Y. Niwatsukino, A. Matsuno, and K. Shibahara: Ext. Abst. third International Workshop on Junction Technology (2002) 32.

11) A. Matsuno, K. Kagawa, Y. Niwatsukino, T.Nire, and K. Shibahara: Proc. ISTC2002, The Electrochemical Society (2003) 148.

12) Y. Yonezawa and T. Minamikawa: Report of the Industrial Research Institute of Ishikawa (1999) 48.

13) A. G. Cullis: Rep. Prog. Phys. 48 (1985) 1155. 